\title{
DOMESTIC INVESTMENT CLIMATE AND FOREIGN DIRECT INVESTMENT IN SOUTH ASIA: A PANEL DATA EVIDENCE
}

\author{
Assad Ullah1 \\ Yang Qingxiang2 \\ Mohammad Abdul Kamal ${ }^{3}$ \\ Zahid Ali 4 \\ Zhongnan university of Economics and Law, Wuhan China
}

\begin{abstract}
Purpose - Developing countries have welcomed foreign direct investment (FDI), since they realized its manifold advantages i.e. capital provision, technological and skills transfer, etc. In the extant literature numerous economic and institutional factors have been identified as potential determinants of FDI, however, domestic investment climate, being a major determinant, has escaped literature on account of unavailability of its reliable data. In this study an endeavor has been made to fill the gap by using index of economic freedom as proxy for domestic investment climate.

Methodology/Sample - The study focuses on four South Asian economies (India, Pakistan, Bangladesh \& Srilanka) for the period 1995-2013, employing panel data regression with random effect. Findings - Results indicate the presence of significant positive relationship between economic freedom and foreign direct investment inflows. The study concludes that economic freedom is a robust and significant determinant of FDI in these South Asian countries. Practical Implications - Policy makers will have to take measures which can improve the level of economic freedom for attracting more FDI to the region. Thus a plan of action is required to create more friendly investment and corruption free environment with high level of trade openness, and to craft efficient monetary and fiscal policies.
\end{abstract}

Keywords : Domestic Investment Climate, Foreign Direct Investment, South Asia

Jel Classification: D920, E220, F210

\footnotetext{
* The material presented by the author does not necessarily portray the viewpoint of the editors and the management of the Institute of Business \& Technology (IBT) Assad Ullah

Yang Qingxiang : assadullah333@yahoo.com

Mohammad Abdul Kamal

:yqx0102@1026.com :mak.1947@yahoo.com : zahidzady@yahoo.com

Zahid Ali

(c) IBTJBS is published by the Institute of Business and Technology (IBT).

Main Ibrahim Hydri Road, Korangi Creek, Karachi-75190, Pakistan.
} 


\section{INTRODUCTION}

Over the past few decades foreign direct investment has attained more importance owing to growth in international commerce and integration of world economies. FDI does not generate principle or interest repayment which it its most salient feature. FDI plays the role of an anchor, since it enhances the economic growth and restructures the developing economies (Wang 2009). Developing countries can alleviate the poverty evil through FDI (Brooks et al., 2010). FDI in developing countries can fill at least three gaps i.e. 'Investment gap' (provision of capital for domestic investment), 'foreign exchange gap' (initial investments providing foreign currency) and finally the 'tax revenue gap' (creating additional economic activities which generates handsome amount of tax revenue) Smith (1997). FDI also assists in the transfer of technological knowledge, managerial skills, creation of job opportunities, enhancement of local competition etc., thereby ultimately improves the economic growth of the host countries.

South Asian economies have realized that inward foreign direct investment is a vital source for capital creation, technology spillover, and knowledge know how, and access to the international markets. That is why most of the countries in South Asian region have taken crucial steps to create a more conducive environment for investment climate. Import substitution policy was pursued by South Asian economies since 1950s. Srilanka launched macroeconomic reforms in 1977 and the rest of South Asian economies followed. To attract FDI, Pakistan and India have made concerted efforts to liberalize their economies. They made obvious changes in their macro-economic, trade and FDI policies. The process of liberalization was speed up in early 1990s in the region.

It's worth mentioning that despite of liberalization, South Asian economies have not realized their growth potential. It may be because, that multinational Corporation's still considers this region to be overly regulated and are hesitant to invest. South Asian countries further need to open their economies through privatization, liberalization and deregulation for enticing more foreign investors. In this way they would become more integrated to the globalized world and ultimately will achieve competitiveness. Put it in other way, in order to promote investment they need more economic freedom. Thus for encouragement of more foreign investors and for the achievement of sustainable economic growth economic freedom is a vital source. Economic freedom is regarded against the government control and centralized planning. This philosophy is in favor of decentralization of economic power and entrepreneurship. In 1996 Gwartney et al termed economic freedom for an individual as "the right to acquire and use his property for trade and any other purpose without any fraud, theft or coercion provided his actions are legal". The importance of foreign direct investment to the economic growth has developed significant interest among the development economists and a notable empirical literature has been evolved regarding the determinants of FDI. These empirical studies have explored the role of numerous variables independently as well as jointly. However in the context South Asia on the relationship between FDI and economic freedom no significant study has captured the joint effect through an index. The main motive of this study is to explore whether, along with other conventional variables used in the literature, economic freedom too is a prime determinant of foreign direct investment in South Asia. 
The rest of the paper is organized as follows. Theoretical background has been presented in the next section. A review of literature comes after. Model has been described in the section next to the review of literature. Data and methodology has been discussed in section 5. Results are presented in sixth section and finally seventh section exhibits conclusion and policy implications.

\section{THEORITICAL BACKGROUND}

The determinants of foreign direct investment have been essayed by many theories. These theories have played vital role in the development of a framework for the egression of foreign direct investment. Hecksher-Ohlin (1933), and Macdougall (1964) were the first two models being developed regarding the determinants of foreign direct investment. According to both models, for the attraction of foreign direct investment low wage rates, high profit margins, and minimum exchange rate risk are necessary. Likewise theories have been developed concerning the multinational companies investment behavior. The one mostly cited by the researchers, working on foreign direct investment, is John Dunning Eclectic Paradigm theory. Dunning (1993) categorized foreign direct investment into three classes. He termed the first class of FDI as market-seeking FDI. The main motive of market-seeking FDI is to fulfill the needs of local market. In the host country, this type FDI replicates the production facilities, thereby also called horizontal FDI. Market size or market growth plays very important role in the attraction of this type of FDI. Significant amount of market-size FDI can be attracted by countries having large market size. Obstacles like transportation cost or tariffs also attract such type of FDI. The second type of FDI according to Dunning is resource-seeking FDI. Here the firm wants to utilize resources of other countries which are not available in their home country, such as input materials like natural resources, cheap labor etc. Low labor cost is the main driver for resource-seeking or vertical FDI. Vertical FDI is attracted to countries with enough natural endowments. In the third type of FDI which is efficiency seeking, firm wants to gain from special economic zones, tax breaks or subsidized land etc.

\section{LITERATURE REVIEW}

The literature regarding FDI in developing countries can be categorized in two ways. The focus of the first category is to examine the impact of foreign direct investment on various macro-economic variables like market size growth, productivity of labor, and technology. A general consensus has been derived from this category of research that, through its effects of technological spillover, foreign direct investment has significant positive impact on labor productivity and economic growth (Rameriz 2000; Zhang 2001).

The focus of the second category is to identify the determinants of FDI by employing panel data for cross countries. The results of this category of research have been found to be controversial. For instance Aseidu (2006) concluded that the relationship between quality infrastructure and FDI is positive. But Mohamed \& Sidropolous (2010) founded 
no significant relationship between quality infrastructure and FDI. Vijayakumar et al., (2010) determined that size of the market strongly encourages foreign direct investment, while on the other hand Mohamed \& Sidropolous, (2010) observed insignificant relationship between FDI and size of the market. In defiance of such differences, the literature of foreign direct investment is thickening day by day and has captured the attention of development economists.

Foreign direct investment is mostly pull in by those developing countries having quality infrastructure, (Sahoo et al., 2014). The expected relationship of FDI with this variable is positive. Majority of the authors have found significant positive relationship between quality infrastructure and foreign direct investment in developing countries (Ngowi, 2001; Asieudu, 2002; Aseidu 2006; Vijayakumar et al., 2010; Srinivasan, 2011). While on the other hand some of the authors have found no significant evidence that quality infrastructure encourages FDI (Cleeve, 2008; Mohamed \& Sidropolous, 2010).

Foreign direct investment will be more inclined to those developing countries having sound financial and economic condition. Balance of payments equilibrium, full employment sustenance, and stability in the level of general price are preconditions to sound financial and economic system. A developing country will attract handsome amount of FDI inflows if it enjoys all the above prerequisites (Cleeve, 2008). For the measurement of economic \& financial soundness, many indicators have been used. The most widely used measure is the rate of inflation, since it gauges the general level of price stability, which in turn is a pre-requisite to economic equilibrium. High or unstable rate of inflation is a vivid sign of instability of economic system and can hinder FDI (Calvo, et al 1994; Buckley et al., 2007). Likewise deficits in the balance of payments too can curtail the free capital mobility, thereby leads to profits repatriation impediment (Schneider and Frey, 1985).

The focus of development economics literature has been shifted towards institutional quality factors in the later year of 1990s. Variables like political instability, poor institutional quality, and corruption were included in the dimension of institutional quality factors. Their expected relationships with foreign direct investment inflows were found to be negative. Countries having corruption-free environment have greater prosperity thereby attract more FDI (Benassy-Quere et al., 2007). Investors feel secure when there is more transparency and low level of corruption. In this regard institutional reforms play a very vital role (Benassy-Quere et al., 2007). Research work of (Aseidu 2006; Mohamed \& Sidropolous, 2010) founded the impact of corruption on FDI inflows significantly negative. In these studies corruption was measured through the index of international country risk guide (ICRG). Likewise result has been obtained by (Cleeve, 2008), through utilizing corruption perceptions index (CPI) of transparency international.

In the context of developing countires majority of the studies backed up negative relationship between FDI and political instability (Corbo and Schmidt-Hebbel 1991; Clarke and Loghan 2008). The institutional quality of a country has been influenced by political instability and the country risk to a great extent. Because, both of them lead to insurrection when the distribution of the resources take place unevenly (Sahu,2008). Notwithstanding, by utilizing the indexes of political \& civil freedom, inconclusive 
outcomes has been obtained by Cleeve (2008) \& Mhlanga et al., (2010). Such sort of results may be probably attributed to the size of the samples which were relatively small in both studies.

Usually the relationship between foreign direct investment inflows and the size of the market is a positive one. Studies which have found positive relationship are Scaperlanda \& Mauer (1969); Root \& Ahmed (1979); Wheeler \& Mody (1992); Tsai (1994); Sahoo (2006). By using the proxy of total number of population Botric and Skuflic (2006) observed significantly negative effect, while on the other hand the outcomes of the research of Mhlanga et al., (2010) and Vijayakumar et al., (2010) come out to be inconclusive. Besides the size of the market, positive relation has been backed up between FDI and economic growth rate in the literature (Ramirez 2000; Chakrabarti, 2001). Countries having sustainable growth rate attract more FDI flows than volatile economies.

Official development funds have been termed as development indicator. In developing countries official development assistance funds are very essential for the improvement of domestic investment climate (Luger and Shetty 1985; McGillivrary, 2009; Mottaleb and Kalirajan 2010). These funds can be channeled for development of infrastructure, social sector and for the acceleration of liberalization and regional integration. For the growth of Global Investment Exchange ODA funds are critical. Intermediary organization can be identified through this way, which in turn can attract projects of foreign direct investment for commercial viability and sustainability.

Higher flow of foreign direct investment will be inclined towards a country if its degree of openness is higher, since by and large most of the multinational corporations are export-oriented. Developing countries can attract more foreign direct investment inflows if they undergo through reforms to open their economies. Majority of the studies have confirmed significant positive relationship between FDI and open economies (Kravis and Lipsey 1982; Aseidu 2006; Choong and Lam, 2010; Vijayakumar et al., 2010; Mhlanga et al., 2010). However Mohamed and Sidiropoulos (2010) have found no statistical significant relationship between foreign direct investment and openness to economy.

When large amount of the budget is kept aside for the expenditures of defense, it entails that minimum amount will be assigned to developmental projects, which is a kind of resources wastage. The mood of the foreign investors is shifted towards those countries who allocate minimum amount for their defense related activities. Hence, the influence of military expenditure on FDI is said to have a negative one. Furthermore, foreign relations may be adversely affected by such kind of practices i.e. the accumulation of weapons. Developing countries regard defense sector as a strategic tool, and relate it to the sovereignty or national defense, thereby allocate fair amount of their budget to this sector. Such policies tend to garble private returns on capital, hence cut down proportion of foreign direct investment De Mello (1999). For the attraction of FDI, the maintenance of the budgetary discipline is a vital condition (Jensen 2003; Choi and Samy 2008). 
In the literature mix results have been observed regarding foreign direct investment and exchange rate. Depreciation of currency of the host country appreciates the currency of the home country, which enables the foreign company to hire additional labor and to buy more raw materials (Lim 2001). This phenomenon lures more foreign investors to the host country. Froot and Stien (1991) also concluded their findings in the same way as Lim (2001). However on the other hand the frequent depreciation in the currency of the host country lead towards uncertainty thereby discourages direct foreign investment.

A panoptic literature has been evolved regarding FDI in developing countries, identifying a number of variables such as, market size, trade openness, exchange rate, inflation rate, political risk etc. The empirical studies in the literature have explored the role of numerous variables independently as well as jointly. However in the context of South Asia on the relationship between FDI and economic freedom no significant study has captured the joint effect through an index. With this background an endeavor has been made in this study by using the index of economic freedom as proxy for domestic investment climate to check it as a determinant of FDI in south Asia.

\section{MODE}

Based on discussion above, we propose the following main model for empirical specification:

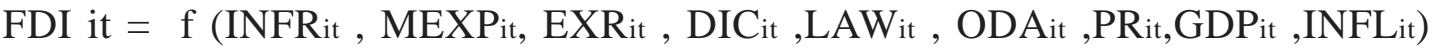
The general form of the equation can be written as:

$\mathrm{FDI}_{i t}=\beta 0+\beta 1 \log \mathrm{INFR}_{i t}+\beta 2 \log \mathrm{MEXP}_{i t}+\beta 3 \log \mathrm{EXR}_{\mathrm{it}}+\beta 4 \log \mathrm{DIC}_{\mathrm{it}}+\beta 5$ LogLAWit+

$$
\text { ß6 LogODAit+ } 37 \text { Log PRit+ } 38 \text { LogGDPit+ } 39 \text { LogINFLit... }
$$

Where FDI it is the dependent variable, Country has been represented by the subscript "i" and time period by the subscript " $t$ ".

Where,

FDI $=$ Foreign Direct investment $($ Million US Dollars)

INFR $=$ No of internet users (per 100 people) being used as aproxy for Infrastructure. MEXP $=$ Military expenditure as a percentage of GDP

$\mathrm{EXR}=$ Exchange rate ( Rupee/US dollar)

$\mathrm{DIC}=$ domestic investment climate being proxied by Index of economic freedom $\mathrm{LAW}=\mathrm{Law}$ and order situation index being taken from International Country Risk Guide(ICRG)

ODA = Official development Assistance (Current US \$)

$\mathrm{PR}=$ Political risk (Government Stability) index being taken from ICRG GDP $=$ Growth rate in GDP ( Annual Percentage)

$\mathrm{INFL}=$ Inflation Rate (Annual percentage change in Consumer price Index) 


\section{DATA AND ESTIMATION TECHNIQUE}

A sample of four South Asian economies for the period 1995-2013, has been taken into consideration in this study. The data for foreign direct investment in US (Million Dollars) and inflation rates i.e. (annual percentage change in consumer price index), has been taken from the annual reports of the central banks official website of Pakistan, India, Bangladesh and Srilanka respectively. Law and order situation and political risk (Government stability) index data has been taken from the International country risk Guide (ICRG). Exchange rate data is taken from the source of International Monetary Fund direction of trade statistics CD-ROM, May 2014. The data of internet users per 100 people (proxy for infrastructure), growth rate in GDP, Military expenditure as a percentage of GDP, and Official development Assistance (Current US \$) has been collected from World Bank online database. Finally the data for Domestic investment climate being measured through the index of economic freedom has been obtained from the Heritage Foundation (2013 estimations). Index of economic freedom consists of wide array of set of policy parameters including freedom of trade, freedom of business, property rights, freedom from corruption and labor and financial freedom. The components have been scaled from 0-100. High score signals Conducive economic environment. In this index equal weights have been assigned to each policy parameter in order to avoid the biasness.

The methodology of panel data regression is employed in the study, so that the dependency of FDI on economic freedom can be explored along with other conventional variables such as growth in the size of market, exchange rate, inflation rate etc.

Constant coefficient model assume that all entities are unvarying and is therefore quite restrictive. The method of estimation in fixed and random effect setting can give more insights. Different constants have been allowed for each section in fixed effect model. Random effect model takes into account that constants are random and are not fixed. According to fixed effect model, the intercept term differs for each country, while random effect model is of the view that there is difference in error term for each country. Both the time series as well as the cross-sectional behavior can be observed simultaneously in random effect setting.

In order to take decision between fixed and random effect Models, Hausman test has been conducted. The result of the test, P-Value (0.683) reveals that random effect is the suitable choice. For the selection between the random effects and pooled OLS, Bruesh-Pagan Lagrange Multiplies test has been conducted. The result of this test, PValue $(0.000<0.05)$ depicts that random effects is the best modeled choice for the data, due to no individual effects. Furthermore the data has been tested for heteroskdasticity and serial auto correlation, which were found not to be present. The Wooldridge test, results the probability value $(0.240)>0.05$, hence depicting no sign of serial auto correlation. 


\section{RESULTS AND DISCUSSION}

Table 5 shows the results when equation (1) is estimated using Random effect method. Before proceeding to the main regression results, the descriptive analysis (Table 2), correlation results (table 3) and VIF test (table 4) are discussed first.

Table 2 depicts descriptive statistics. In the above table variables such FDI and official development assistance are highly skewed towards their respective maximum value. Significant improvement is observed in the values of the variables. In the region the mean value of FDI can be observed to be moderate hinting towards reasonable rise in FDI. Amid all variables the mean value of official development assistance displays higher inclination towards the maximum, thereby indicating that this might be cardinal variable to pull in FDI towards South Asian region. The average values of exchange rate and economic freedom also give indication that both of variables have enough potential to attract FDI inflows. Highest spread value has been demonstrated by political risk (Govt Stability) as indicated by its standard deviation. The rest of variables have levelheaded description.

Correlation analysis of all variables being taken into consideration in the study of four South Asian nations i.e. Pakistan, India, Srilanka, and Bangladesh has been given in table 2. It has been revealed from the results of the study that the relationship between FDI, infrastructure, law and order situation and official development assistance is significant and positive. Thus it has been observed that most of the variables included in the study have the expected directions. Also the variables in the model have found to be not strongly correlated; hence the collinearity problem in the model does not exist.

In table 4 the variance inflation factor (VIF) results and the tolerance level have been depicted. The individual variance inflation factor value is less than $10 \%$ in the analysis, while the mean value of VIF is 2.37 , which indicates that overall data is depicting a meaningful picture and is thereby satisfactory for the estimation. It also indicates that no multi-collinearity issues have been found in the data while estimating the models.

Table 5 exhibits the regression results. Nine models have been constructed. Subsequent inclusion of explanatory variables provides broader picture and their association with the explained variable (FDI). The R-square value shows improvement when the impulses are added one by one which depicts improvement in the value of the response variable.

Across all the nine models, the coefficient of infrastructure has been found significant at the level of $1 \%$, depicting a well-knit positive relationship with FDI. This result is in conformity with findings of Srinivasan, (2011) and Sahoo et al., (2014) in the literature. Transportation cost is a vital variable for multi-national companies especially operating outside their home country. An improved infrastructure has been observed in the region of South Asia and considerable decline in the transportation cost has been witnessed during the last decade according to the report of (World Bank 2009). Furthermore, reduction in trade costs assists MNEs to extend their production operations in various locations and affiliates, known as vertical integration. 
As expected, negative sign has been observed for the coefficient of military expenditure. Less amount of FDI is attracted by a country having high military expenditures. Large amount of military expenditure is an indication that South Asian economies have little space for development, lesser macro-economic stability, thereby adversely affect the inflows of FDI. For the attraction of FDI, the maintenance of the budgetary discipline is a vital condition (Jensen 2003; Choi and Samy 2008).

The relationship of exchange rate with foreign direct investment has been found to be negative and significant as expected. In the literature Ahmed and Malik (2009) also found likewise results. Negative coefficient of exchange rate is an indication that currency depreciation makes the prices of the goods relatively cheaper and more affordable for the host companies to build up their production operations in the host country. Exchange rate depreciation makes exports more competitive in international markets thereby enabling the multinational firms to use those countries as platform for their exports. Currency depreciation of the host country enables the investors of home country to purchase additional raw materials and to hire cheap labor with the same amount of currency; hence they are willing to invest more directly in the host country.

A positive and significant association is witnessed between FDI and domestic investment climate in selected countries of South Asian region. There is an economic rationale behind this association as economic freedom consists of wide array of set of policy parameters including freedom of trade, freedom of business, property rights, freedom from corruption and labor and financial freedom. A country will lure more flows of foreign direct investment having low level of interference in the affairs of the businesses and giving them the right to open and close operations hence, allowing them to use their wealth, the way they want. In the same way corruption free environment of the country will give more confidence to foreign investors to invest there without any hesitation.

FDI is attracted by a country having sound law and order situation. Foreign investors always keep this factor at utmost priority while scanning countries for direct investment. For investors the security pursuit is second to none than the profit pursuit when they are taking decision about the place of investment. Foreign investors perceive that countries having maximum sectarian violence and other security issues are not suitable for investment and try to remain all aloof from investing in their territories. The respect for rule of law and property rights makes the environment more conducive for foreign direct investment (Clarke \& Logan 2008). Thus foreign investors tend to invest in countries having proper arrangement for their security. An expected positive sign has been obtained for the coefficient of law and order from the results of the study.

In the results the coefficient of official development assistance is found to be significant at $5 \%$ level throughout all the designed models of the study, portraying a significant positive relation with foreign direct investment. In the literature these results confirm the findings of (McGillivrary, 2009; Mottaleb and Kalirajan 2010). Their results suggested that official development assistance funds are indispensable for the betterment of domestic investment climate in third world countries. Such kind of development funds shape infrastructure and also highlights a nation's good terms with international 
arena.

Foreign investors do not consider countries which are vulnerable to sudden political changes. Political factor is vital component in attracting FDI especially in developing countries. MNEs are inclined towards those nations where government is stable and where ethnic tension and the number of conflicts are at minimum. Foreign investors are highly sensitive to political changes (Busse and Hefeker, 2003). In comparison to autocratic governments democratic governments which are politically stable lure large part of FDI inflows Schneider and Frey (1985). The respect of rule of law and property rights makes the environment more conducive for foreign direct investment (Clarke \& Logan 2008). An expected negative coefficient for political risk (Government stability) has been noticed from the results of the study. This result is in concordance with the finding of Corbo and Schmidt-Hebbel (1991); Barro (1991); Buckley et al., (2007) and Sahu (2008). They too backed up negative relationship of political instability with FDI.

The current demand is presented by the size of the market, whereas the growth exhibits the prospective demand. The higher the level of economic growth, higher will be the market opportunities. Market growth is considered to be a significant factor for the enhancement of foreign direct investment flows. The growth rate in GDP is found to have positive impact over the inflows of FDI but, insignificant. Our result is in conformity with Mhlanga et al., (2010) and Vijayakumar et al., (2010) in the literature. Limited support exists regarding this determinant of FDI in the previous empirical studies in contrast to the market size variable Goldberg (1972); Root \& Ahmed (1979); Tsai (1994) and Mohamed and Sidiropoulos (2010).

Negative coefficient has been obtained for the inflation variable in the study which is aligned with the literature. Since inflation measures the general level of price stability, it is considered to be a pre-requisite to economic equilibrium. High or unstable rate of inflation is vivid sign of instability of economic system and can hinder foreign direct investment (Botric and Skuflic, 2006; Buckley et al., 2007). Cost of capital of the user increases when there is hike in the rate of inflation, thus influences the profitability of FDI negatively. Higher rate of inflation exhibits indiscreet monitory and fiscal policies like continual deficits in budget, inordinate supply of money, and badly managed exchange rate regime (Calvo, et al 1996). Such indicators discourage foreign investors. In order to gauge the macro-economic instability the proxy of inflation is used, which in turn has a strong relationship with political instability.

\section{CONCLUSION AND POLICY IMPLICATIONS}

It is has been acknowledged in the literature of development economics that, in the perspective of developing countries foreign direct investment acts as a vital component for their growth dynamics. The motive behind this study is to investigate the determinants of FDI by employing panel regression model for four South Asian developing countries for the period 1995-2013. This study makes a noteworthy contribution to the literature of foreign direct investment, as it has explored the domestic investment climate as a robust determinant of FDI in South Asia, which escaped the literature for the unavailability 
of its reliable data.

The outcome of the study proposes that a finer domestic investment climate, developed infrastructure and considerable official development assistance funds have significant contribution to boost the inflows of FDI, while the influence of exchange rate, military expenditures, and inflation on the inflows of FDI is negative. Variables such as law and order, political risk (Government stability), GDP growth and inflation turned out to be insignificant in the study, but all of them have obtained their correct signs in association to foreign direct investment.

This study discovered that domestic investment climate which is not causative to economic freedom will probably affect negatively other positive determinants of FDI. As a result, policy makers will have to chalk out policies that can improve the level of economic freedom. This implies that the policy makers are required to create a climate that is more investment friendly, design efficient monetary and fiscal policies, makes trade more open and ensure corruption-free environment. By doing so, a sound economic environment will likely to be fostered, thereby attracting more inflows of FDI to the region.

\section{ACKNOWLEDGEMENT}

First of all with a profound gratitude, we are thankful to Almighty Allah forgiving us success, knowledge and understanding without which we would not been capable of completing this research paper.

We are also profoundly grateful to all our family members whose endurance and understanding have played a significant role in our success by sacrificing the important family time and supporting us all over the research work.

We are finally thankful to the editor, reviewers and IBT specially who provided us with the opportunity to publish our research paper in this esteemed journal.

\section{REFERENCES}

Ahmad, E. and A. Malik (2009). "Financial sector development and economic growth: An empirical analysis of developing countries." Journal of Economic Cooperation and Development 30(1): 17-40.

Asiedu, E. (2002). "On the determinants of foreign direct investment to developing countries: is Africa different?" World development 30(1): 107-119.

Asiedu, E. (2006). "Foreign direct investment in Africa: The role of natural resources, market size, government policy, institutions and political instability." The World Economy 29(1): 63-77.

Barro, R. (1991). "Economic Growth in a Cross Section of Countries", Quarterly journal of Economics, Vol. 106."

Bénassy-Quéré, A., et al. (2001). "Foreign Direct Investment and Company Taxation in Europe. ENEPRI Working Paper No. 4, April 2001."

Botric, V. and L. Škuflic (2006). "Main determinants of foreign direct investment in 
the southeast European countries." Transition Studies Review 13(2): 359-377.

Brooks, D., et al. (2010). "Closing Development Gaps: Challenges and Policy Options:

ADB Economics Working Paper Series 209." Manila: Asian Development Bank.

Buckley, P. J., et al. (2007). "The determinants of Chinese outward foreign direct investment." Journal of International Business Studies 38(4): 499-518.

Busse, M. and C. Hefeker (2007). "Political risk, institutions and foreign direct investment." European journal of political economy 23(2): 397-415.

Calvo, G. A., et al. (1994). "Inflows of capital to developing countries in the 1990s: causes and effects."

Chakrabarti, A. (2001). "The determinants of foreign direct investments: Sensitivity analyses of cross-country regressions." Kyklos 54(1): 89-114.

Choi, S. W. and Y. Samy (2008). "Reexamining the effect of democratic institutions on inflows of foreign direct investment in developing countries." Foreign Policy Analysis 4(1): 83-103.

Choong, C.-K. and S.-Y. Lam (2010). "The determinants of foreign direct investment in Malaysia: A revisit." Global Economic Review 39(2): 175-195.

Clarke, R. and T.-M. L. Logan (2008). "EMERGING FDI PATTERNS IN THE CARICOM REGION." International Journal of Business Research 8(1).

Cleeve, E. (2008). "How effective are fiscal incentives to attract FDI to Sub-Saharan Africa?" The Journal of Developing Areas 42(1): 135-153.

Corbo, V. and K. Schmidt-Hebbel (1991). "Public policies and saving in developing countries." Journal of Development Economics 36(1): 89-115.

Culem, C. G. (1988). "The locational determinants of direct investments among industrialized countries." European economic review 32(4): 885-904.

De Mello, L. R. (1999). "Foreign direct investment-led growth: evidence from time series and panel data." Oxford economic papers 51(1): 133-151.

Dunning, J. H. and S. M. Lundan (2008). Multinational enterprises and the global economy, Edward Elgar Publishing.

Goldberg, M. A. (1972). "The determinants of US Direct Investment in the EEC: Comment." The American Economic Review: 692-699

Gwartney, J. D., et al. (1999). "Economic freedom and the environment for economic growth." Journal of Institutional and Theoretical Economics (JITE)/Zeitschrift für die gesamte Staatswissenschaft: 643-663.

Jensen, N. M. (2003). "Democratic governance and multinational corporations: Political regimes and inflows of foreign direct investment." International organization 57(03): 587-616.

Kinoshita, Y. and N. F. Campos (2003). "Why does FDI go where it goes? New evidence from the transition economies."

Kravis, I. B. and R. E. Lipsey (1982). "The location of overseas production and production for export by US multinational firms." Journal of international economics 12(3): 201-223.

Lim, E.-G. (2001). Determinants of, and the relation between, foreign direct investment and growth: a summary of the recent literature, International Monetary Fund.

Loree, D. W. and S. E. Guisinger (1995). "Policy and non-policy determinants of US equity foreign direct investment." Journal of International Business Studies: 281-299. 
McGillivray, M. (2009). "Aid, economic reform, and public sector fiscal behavior in developing countries." Review of Development Economics 13(3): 526-542.

Mhlanga, N., et al. (2010). "Understanding foreign direct investment in the southern African development community: an analysis based on project-level data." Agricultural Economics 41(3-4): 337-347.

Mohamed, S. E. and M. G. Sidiropoulos (2010). "Another look at the determinants of foreign direct investment in MENA countries: an empirical investigation." Journal of Economic Development 35(2): 75-95.

Mottaleb, K. A. and K. Kalirajan (2010). "Determinants of foreign direct investment in developing countries a comparative analysis." Margin: The Journal of Applied Economic Research 4(4): 369-404.

Ngowi, H. P. (2001). "Can Africa increase its global share of foreign direct investment (FDI)?" West Africa Review 2(2).

Ramirez, M. (2000). "Foreign direct investment in Mexico: a cointegration analysis." Journal of Development Studies 37(1): 138-162.

Root, F. R. and A. A. Ahmed (1979). "Empirical determinants of manufacturing direct foreign investment in developing countries." Economic Development and Cultural Change: 751-767.

Rugman, A. M., et al. (1998). The determinants of Japanese foreign direct investment flows to the European community, 1963-1990. Multinational Location Strategy, Emerald Group Publishing Limited: 29-49.

Sahoo, P. (2006). Foreign direct investment in South Asia: policy, trends, impact and determinants, ADB Institute Discussion Papers.

Sahoo, P., et al. (2013). Foreign Direct Investment in South Asia: Policy, Impact, Determinants and Challenges, Springer Science \& Business Media.

Sahu, M. (2008). Inverted Development and Oil Producers in sub-Saharan Africa: a Study, University of Mumbai.

Scaperlanda, A. E. and L. J. Mauer (1969). "The determinants of US direct investment in the EEC." The American Economic Review: 558-568.

Schneider, F. and B. S. Frey (1985). "Economic and political determinants of foreign direct investment." World development 13(2): 161-175.

Smith, S. (1997). "Restrictive policy toward multinationals: Argentina and Korea." Case Studies in Economic Development: 178-189.

Srinivasan, P. (2011). "Determinants of foreign direct investment in SAARC nations: An econometric investigation." The IUP Journal of Managerial Economics 9(3): 26-42.

Tsai, P.-L. (1994). "Determinants of foreign direct investment and its impact on economic growth." Journal of Economic Development 19(1): 137-163.

Vijayakumar, N., et al. (2010). "Determinants of FDI in BRICS Countries: A panel analysis." International Journal of Business Science and Applied Management 5(3): 1-13.

Wang, M. (2009). "Manufacturing FDI and economic growth: evidence from Asian economies." Applied Economics 41(8): 991-1002.

Wheeler, D. and A. Mody (1992). "International investment location decisions: The case of US firms." Journal of international economics 33(1): 57-76.

Zhang, K. H. (2001). "Does foreign direct investment promote economic growth?

Evidence from East Asia and Latin America." Contemporary Economic Policy 19(2): 175-185. 


\section{APPENDIX}

Table 1: VARIABLES, DEFINITIONS AND THEIR EXPECTED SIGNS

\begin{tabular}{|l|l|c|}
\hline Variable & Definition & Expected sign \\
\hline Infrastructure & No of internet users (per 100 people) & Positive \\
\hline Military Expenditures & Military expenditure as a percentage of GDP & Negative \\
\hline Exchange Rate & Exchange rate ( Rupee/US dollar) & Negative \\
\hline Domestic investment climate & $\begin{array}{l}\text { Domestic investment climate being proxied by Index } \\
\text { of economic freedom }\end{array}$ & Positive \\
\hline Law and order & Law and order situation index & Positive \\
\hline Official Development Assistance & Official development Assistance (Current US \$) & Positive \\
\hline Political Risk & Political risk (Government Stability) index & Positive \\
\hline GDP Growth & Growth rate in GDP (Annual Percentage) & Positive \\
\hline Inflation & Annual percentage change in Consumer price Index) & Negative \\
\hline
\end{tabular}

Table 2: DESCRIPTIVE ANALYSIS

\begin{tabular}{|l|c|c|c|c|c|}
\hline Variable & No of Obs. & Mean & Std. Dev. & Minimum & Maximum \\
\hline FDI & 76 & 2.943 & 0.7186 & 0.7781 & 4.344 \\
\hline Infrastructure & 76 & 0.472 & 0.3580 & 0.0764 & 1.340 \\
\hline Military Expenditures & 76 & 0.436 & 0.2027 & 0.0645 & 0.7935 \\
\hline Exchange Rate & 76 & 1.798 & 0.1510 & 1.535 & 2.12 \\
\hline Domest. investment climate & 76 & 1.734 & 0.0415 & 1.612 & 1.82 \\
\hline Law \& Order & 76 & 0.484 & 0.1166 & 0.0177 & 0.6020 \\
\hline Official Develop Assistance & 76 & 9.061 & 0.2672 & 8.418 & 9.54 \\
\hline Polit. Risk (Govt Stability) & 76 & 1.382 & 2.063 & 0.4771 & 10.66 \\
\hline GDP Growth & 76 & 0.721 & 0.1770 & 0.0820 & 0.9872 \\
\hline Inflation & 76 & 0.859 & 0.2066 & 0.2857 & 1.35 \\
\hline
\end{tabular}


Table 3: CORRELATION ANALYSIS

\begin{tabular}{|l|c|c|c|c|c|c|c|c|c|c|}
\hline & LFDI & LINFR & LMEXP & LEXR & LDIC & LLAW & LODA & LPR & LGDP & INFL \\
\hline LFDI & 1.000 & & & & & & & & & \\
\hline LINFR & $0.502^{*}$ & 1.000 & & & & & & & & \\
\hline LMEXP & 0.0686 & 0.0888 & 1.000 & & & & & & & \\
\hline LEXR & -0.1684 & $0.516^{*}$ & 0.0194 & 1.000 & & & & & & \\
\hline LDIC & -0.0976 & 0.1800 & $0.6344^{*}$ & $0.4969^{*}$ & 1.000 & & & & & \\
\hline LLAW & $0.356^{*}$ & 0.1089 & $0.4653^{*}$ & $-0.3098^{*}$ & 0.1449 & 1.000 & & & & \\
\hline LODA & $0.514^{*}$ & $0.2811^{*}$ & $-0.2963^{*}$ & $-0.3032^{*}$ & $-0.552^{*}$ & -0.05 & 1.000 & & & \\
\hline LPR & 0.0183 & 0.1412 & $-0.3305^{*}$ & 0.1387 & -0.0875 & -0.16 & 0.150 & 1.000 & & \\
\hline LGDP & 0.2194 & 0.0807 & $-0.2805^{*}$ & -0.1400 & -0.2172 & 0.113 & 0.005 & 0.0869 & 1.000 & \\
\hline LINFL & 0.0889 & $0.227^{*}$ & $0.2362^{*}$ & 0.2094 & $0.275^{*}$ & 0.212 & 0.034 & 0.0508 & -0.142 & 1.000 \\
\hline
\end{tabular}

Table 4: VARIANCE INFLATION FACTOR TEST

\begin{tabular}{|l|c|c|}
\hline Variables & VIF & 1/VIF \\
\hline Infrastructure & 2.83 & 0.35 \\
Military Expenditures & 3.03 & 0.33 \\
Exchange Rate & 3.78 & 0.26 \\
Domestic investment climate & 3.43 & 0.29 \\
Law and order & 1.90 & 0.52 \\
Official Development Assistance & 2.58 & 0.38 \\
Political Risk & 1.21 & 0.82 \\
GDP Growth & 1.34 & 0.74 \\
Inflation & 1.25 & 0.80 \\
& & \\
\hline Mean VIF & & - \\
\hline & $\mathbf{2 . 3 7}$ & \\
\hline
\end{tabular}


Table 5: DOMESTIC INVESTMENT CLIMATE AND FDI IN SOUTH ASIA

\begin{tabular}{|c|c|c|c|c|c|c|c|c|c|}
\hline & $\begin{array}{l}\text { Log FDI } \\
(\operatorname{Mod} 1)\end{array}$ & $\begin{array}{r}\text { Log FDI } \\
(\operatorname{Mod} 2)\end{array}$ & $\begin{array}{r}\text { Log FDI } \\
(\operatorname{Mod} 3)\end{array}$ & $\begin{array}{l}\text { Log FDI } \\
(\operatorname{Mod} 4)\end{array}$ & $\begin{array}{l}\text { Log FDI } \\
(\operatorname{Mod} 5)\end{array}$ & $\begin{array}{l}\text { Log FDI } \\
(\operatorname{Mod} 6)\end{array}$ & $\begin{array}{l}\text { Log FDI } \\
(\operatorname{Mod} 7)\end{array}$ & $\begin{array}{l}\text { LogFDI } \\
(\operatorname{Mod} 8)\end{array}$ & $\begin{array}{l}\text { Log FDI } \\
(\operatorname{Mod} 9)\end{array}$ \\
\hline \multirow[t]{2}{*}{ LogINFR } & $0.89 * * *$ & $0.85 * * *$ & $1.6^{* * *}$ & $1.65^{* * *}$ & $1.56^{* * *}$ & $1.13 * * *$ & $1.14 * * *$ & $1.01 * * *$ & $1.00 * * *$ \\
\hline & $(0.18)$ & $(0.22)$ & $(0.31)$ & $(0.24)$ & $(0.23)$ & $(0.15)$ & $(0.15)$ & (0.09) & $(0.11)$ \\
\hline \multirow[t]{2}{*}{ LogMEXP } & & -0.36 & 0.03 & -0.24 & -0.41 & -0.42 & -0.51 & -0.26 & -0.25 \\
\hline & & $(0.29)$ & $(0.44)$ & $(0.52)$ & $(0.59)$ & $(0.68)$ & $(0.66)$ & $(0.86)$ & $(0.91)$ \\
\hline \multirow[t]{2}{*}{ LogEXR } & & & $-2.76 * *$ & $-3.10 * *$ & $-2.75^{* *}$ & $-1.95 * * *$ & $-1.93 * *$ & $-1.64 * *$ & $-1.57 * *$ \\
\hline & & & (1.19) & (1.06) & $(0.45)$ & $(0.51)$ & $(0.47)$ & $(0.61)$ & $(0.73)$ \\
\hline \multirow[t]{2}{*}{ LogDIC } & & & & $2.12 * *$ & $1.82(* *)$ & $4.05 * *$ & $4.3 * *$ & $4.33 * *$ & $4.49 * *$ \\
\hline & & & & (1.09) & $(1.10)$ & (1.39) & $(1.53)$ & (1.63) & (1.53) \\
\hline \multirow[t]{2}{*}{ LogLAW } & & & & & 0.81 & 1.25 & 1.27 & 1.15 & 1.23 \\
\hline & & & & & $(1.45)$ & $(1.53)$ & $(1.49)$ & $(1.57)$ & (1.48) \\
\hline \multirow[t]{2}{*}{ LogODA } & & & & & & $0.89 * *$ & $0.92 * *$ & $1.07 * *$ & $1.10^{*}$ \\
\hline & & & & & & $(0.30)$ & 0.33 & 0.38 & 0.46 \\
\hline \multirow[t]{2}{*}{ LogPR } & & & & & & & $-0.02)$ & -.01 & -0.01 \\
\hline & & & & & & & $(.01)$ & $(.01)$ & $(.01)$ \\
\hline \multirow[t]{2}{*}{ LogGDP } & & & & & & & & 0.59 & 0.57 \\
\hline & & & & & & & & (.66) & (.64) \\
\hline \multirow[t]{2}{*}{ LogINF } & & & & & & & & & -0.15 \\
\hline & & & & & & & & & $(0.38)$ \\
\hline \multirow[t]{2}{*}{ Constant } & $2.51 * * *$ & $2.69 * * *$ & $7.14 * *$ & 4.17 & 3.78 & -9.67 & -10.3 & -12.7 & -13.3 \\
\hline & $(0.27)$ & $(0.29)$ & $(2.28)$ & $(3.40)$ & $(2.37)$ & $(4.93)$ & $(5.41)$ & $(6.69)$ & $(7.38)$ \\
\hline Observations & 76 & 76 & 76 & 76 & 76 & 76 & 76 & 76 & 76 \\
\hline No of countries & 04 & 04 & 04 & 04 & 04 & 04 & 04 & 04 & 04 \\
\hline R-Square & 0.2519 & 0.2319 & 0.5005 & 0.5056 & 0.5159 & 0.5657 & 0.5682 & 0.5842 & 0.5857 \\
\hline
\end{tabular}

